\title{
Interrelationships between urban drainage and geomorphological risk in Garanhuns - PE
}

This research aimed to analyze the interaction between surface water drainage and the geomorphological risk in the urban area of Garanhuns, PE, Brazil. This region, driven by the national policy of coffee eradication, implemented in 1965 by the Brazilian Institute of Coffee - IBC, has maximized its urban occupation. This constant advance of the urban perimeter, combined with the geomorphological characteristics and the rainfall index that is atypical in this semiarid region creates a scenario of high predisposition to geomorphological risks. The analysis was carried out by equating the existing interrelationships in the local landscape, based on a model of the geomorphological risk of the urban area, as well as photographs obtained on-site. The referred model was created through the application of the infinite slope theory, in order to determine the terrain's stability. Based on the results, conclusions about the current situation of the urban occupation and drainage were inferred and a scenario of high geomorphological risk was found, originated by consequences of anthropic actions, driven by inadequate urban planning. Moreover, deficiencies were found in the urban drainage system, which aggravates the geomorphological risk in a considerable way since it amplifies the effects of erosion, allowing the occurrence of mass movements.

\section{Inter-relações entre a drenagem urbana e o risco geomorfológico em Garanhuns-PE}

\begin{abstract}
A presente pesquisa foi conduzida com o objetivo de analisar a interação entre a drenagem urbana superficial e o risco geomorfológico na área urbana de Garanhuns, PE, Brasil. A região tem maximizado a ocupação urbana, impulsionada pela política nacional de erradicação do café, implantada em 1965 pelo Instituto Brasileiro do Café - IBC. Esse constante avanço do perímetro urbano, aliado às características geomorfológicas e o índice pluviométrico atípico no semiárido, configura um cenário de predisposição a riscos geomorfológicos. A análise foi realizada pelo equacionamento das inter-relações existentes na paisagem local, tendo como base a modelagem do risco geomorfológico da área urbana, assim como o registro fotográfico realizado a partir de visitas técnicas. A referida ação, foi realizada a partir da aplicação da teoria do talude infinito, para determinação de estabilidade do relevo. Por fim, inferiu-se sobre a atual situação da ocupação e drenagem urbana, face ao risco geomorfológico. Dessa forma, constatou-se um cenário de alto risco geomorfológico, como consequência das ações antrópicas, impulsionado pelo inadequado planejamento urbano. Identificou-se ainda, deficiências na drenagem urbana, o que agrava de forma considerável o risco geomorfológico ao ampliar os efeitos da erosão e propiciar a ocorrência de movimentos de massa.
\end{abstract}

Palavras-Chave: Erosão; Geomorfologia; Escoamento superficial; Planejamento urbano.

Topic: Tecnologia, Modelagem e Geoprocessamento

Reviewed anonymously in the process of blind peer.
Received: $28 / 04 / 2021$

Approved: 29/05/2021
João Vitor de Almeida Bezerra (D)

Universidade Federal Rural de Pernambuco, Brasil

http://lattes.cnpq.br/0577287275286569

http://orcid.org/0000-0001-8767-4646

j.vitor.almeida@outlook.com

Ricardo Brauer Vigoderis (iD

Universidade Federal Rural de Pernambuco, Brasil

http://lattes.cnpq.br/8447376601980922

http://orcid.org/0000-0001-8775-972X

vigoderis@hotmail.com

\section{Héliton Pandorfi}

Universidade Federal Rural de Pernambuco, Brasil

http://lattes.cnpq.br/7981297368478991

http://orcid.org/0000-0002-2037-8639

hpandorf@hotmail.com

\author{
Felippe Pessoa de Melo (iD \\ Centro Universitário UniAGES, Brasil \\ http://lattes.cnpq.br/9232465770550351 \\ http://orcid.org/0000-0001-5363-016X \\ felippemelo@hotmail.com \\ Douglas Vieira Gois (iD \\ Centro Universitário UniAGES, Brasil \\ http://lattes.cnpq.br/3364013420770381 \\ http://orcid.org/0000-0003-0861-400X \\ douglasgeograf@hotmail.com \\ Rosemeri Melo Souza (io \\ Universidade Federal de Sergipe, Brasil \\ http://lattes.cnpq.br/3339056948815053 \\ http://orcid.org/0000-0002-5916-3598 \\ rosemerimeloesouza@gmail.com
}

Referencing this:

BEZERRA, J. V. A.; VIGODERIS, R. B.; PANDORFI, H.; MELO, F. P.; GOIS, D. V.; SOUZA, R. M.. Interrelationships between urban drainage and geomorphological risk in Garanhuns - PE. Revista Ibero Americana de Ciências Ambientais, v.12, n.5, p.734-743, 2021. DOI:

http://doi.org/10.6008/CBPC2179-6858.2021.005.0057 


\section{INTRODUCTION}

The increasing concentration of the human population in urban areas, especially in developing countries, causes several environmental problems related to the exposition of people and their possessions due to the occupation of risk areas (MONTEIRO et al., 2016). The urban environment results from intrinsic relationships between several variables related to the processes of land use and physical geography, such as: terrain, rainfall index, soil, evapotranspiration, atmospheric circulation and vegetation cover, economic cycles, cultural and religious particularities, fixation and expansion of the urban polygon.

The expansion of the urban area and the geomorphology act as catalysts to the processes of land use in the municipality of Garanhuns, state of Pernambuco, Brazil. To analyze the inter-relationships of the surface water drainage and the geomorphological risk in question, without considering the aforementioned physical variables and their correlations and also spatial and temporal scales, doesn't meet the intrinsic needs of adequate environmental planning.

Based on this, the municipality of Garanhuns has three main variables, namely: the terrain, the rainfall index that is atypical in the region and the intense process of maximization of the urban area which according to Melo (2013) was driven by the national policy of coffee eradication, implemented in 1965 by the Brazilian Institute of Coffee - IBC. According to elevation data of the ASTER GDEM v2 program administered by The National Aeronautics and Space Administration - NASA (2011), the terrain of Garanhuns has a high topographic range, with an average altitude of $824 \mathrm{~m}$, while some geographical features exceed $1.013 \mathrm{~m}$, as in the local hill named Morro do Magano.

The second main variable, namely the rainfall index, is high for a municipality located in the northeastern region of Brazil. According to the historical series of the National Institute of Meteorology INMET (2013), the average annual rainfall is $886,5 \mathrm{~mm}$, where July is the month with the highest average rainfall $(148,1 \mathrm{~mm})$. Lastly, the national coffee eradication policy in areas considered to be of low productivity implemented by the IBC in 1965, which subsidized the replacement of the coffee monoculture by extensive dairy farming. This new activity, in addition to requiring less manpower, required a new profile of rural workers, that is, a large number of farmers were replaced by a small number of herdsmen. Thus, farmers started to settle in urban areas of cities like Garanhuns.

According to Gois et al. (2011), the phenomenon of fast urbanization, caused by late development, especially in countries considered to be underdeveloped, brought a series of changes to the environmental systems of the areas occupied by cities. In this sense, the urban expansion presents itself as an emblematic phenomenon that gives rise to many contradictory observations, where real estate speculation predominates at the expense of the environmental systems of the urban area.

It is of human nature to modify the landscape so that it is able to provide comfort and resources in an efficient way in temporal intervals compatible with the necessities of the population. However, throughout the years, this environmental intervention became increasingly latent and faster, due to the fact that the time needed for the landscape to recover after being exploited wasn't taken into consideration, triggering and/or intensifying processes such as: soil degradation, leaching, mass 
movements, water erosion, fires, removal of flora, minimization of fauna, loss of soil productivity and eutrophication (MELO et al., 2016). Risk researches have as one of their most important tasks, to support the decision makers with clear and precise criteria and processes. These criteria are fundamental for the preparation of policies related to risk management (OLIVEIRA et al., 2018). In this context, this research aimed to analyze the interaction between surface water drainage and the geomorphological risk in the urban area of Garanhuns, PE, Brazil.

\section{METHODOLOGY}

The municipality of Garanhuns (Fig. 1), is located in the microregion of Alto Capibaribe, occupying an area of $458,55 \mathrm{~km}^{2}$. It shares borders with the municipalities of Capoeiras, Jucati, Correntes, Lagoa do Ouro, Brejão, Terezinha, São João, Palmeirina, Saloá, Paranatama and Caetés.
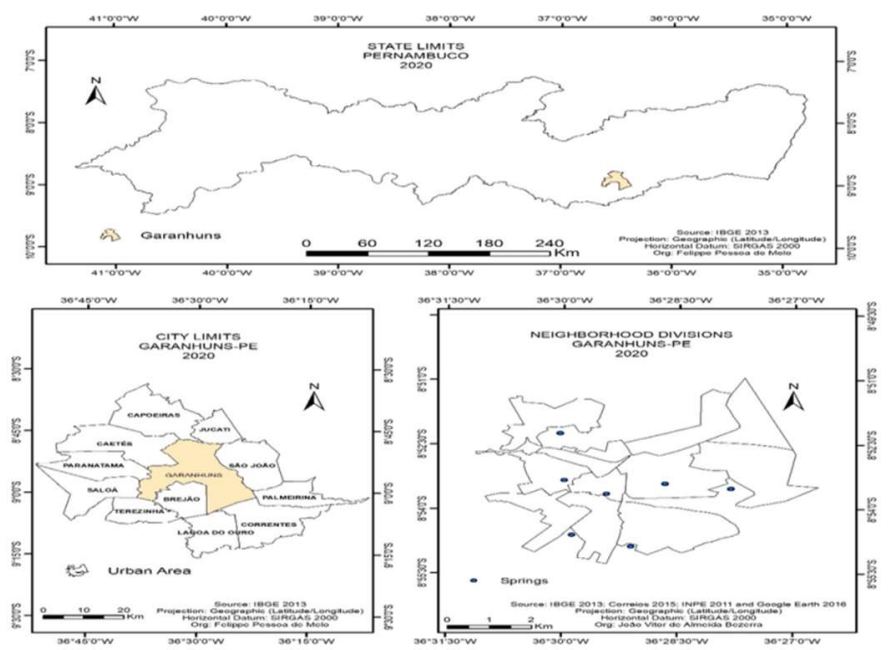

Figure 1: Map of the study area. Source: IBGE (2013); CORREIOS (2015); INPE (2011) and GOOGLE EARTH (2016).

While the municipality is under the domains of the semiarid climate, it shows itself as an area of exception, with mild temperatures and a high rainfall index for an area located in the semiarid region. According to Melo (2016), the historical rainfall series of Garanhuns, tend to show periods of high concentration of rain, even in years considered to be dry. The June to August quarter stood out, with an average rainfall of $229,3 \mathrm{~mm}$, whereas in June 2010 the registered rainfall index was 427,50 mm, characterizing it as the rainiest month of all of the analyzed meteorological series. This rainfall profile, contributes to the mutability of the geomorphological risk.

Originally, Garanhuns had a vegetation cover made of Atlantic Forest and Hypoxerophytic Caatinga. This natural cover was removed due to several reasons, namely: to create pasture for the dairy cattle, to provide areas for settlement and expansion of the urban area, to provide wood for bakery furnaces, to provide coal and fires for the festivities during the month of June. The region's terrain (Fig. 2) has several undulated geographical features, especially hills, with an average altitude of $824 \mathrm{~m}$, exceeding $1.013 \mathrm{~m}$ like in the local hill named Morro do Magano. Among the geographical features are valleys, which have steep slopes and flattened bottoms at the limits of the urban area. 


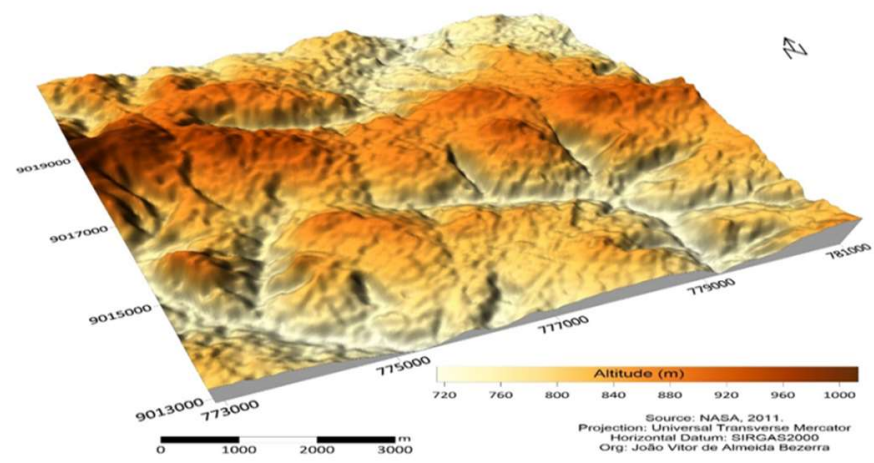

Figure 2: Digital Elevation Model of the Urban Perimeter of Garanhuns. Source: NASA (2011).

According to the Brazilian Agricultural Research Corporation - EMBRAPA (2001), the soil is mostly made of red yellow acrisol. This research implemented analyses that were integrated to the study area, equating the existing inter-relationships of the landscape in question, considering both natural processes and the ones related to anthropogenic activity.

Initially, elevation data with a spatial resolution of $30 \mathrm{~m}$ was obtained from the ASTER GDEM v2 which is a project administered by NASA (2011). Posteriorly, the data was processed in the software Global Mapper 16, in order to change the projection and datum to UTM - Universal Transverse Mercator and SIRGAS2000, respectively. In order to quantify the geomorphological risk, an algorithm was developed in the extension called Model Builder of the software ArcMap 10.3.1, that applies the infinite slope model for the condition of saturated soil in the study area. The results were exported to the software Surfer 15 , in order to create thematic maps that show the results on top of the 3D model of the area.

According to Schor et al. (2007) the infinite slope model Eq. (1) is used to analyze translational failures in slopes, and it results in a Factor of Safety that reflects the relation between strength of the slope and the current load. The results were layered on top of a 3D model of the area, in order to provide a general analysis of the vulnerability of the natural slopes.

$$
\mathbf{F S}=\frac{\left[\mathbf{c}^{\prime} / \cos ^{2} \beta \tan \varphi+\left(\mathbf{q}_{0}+\gamma H\right)+\left(\gamma_{\text {buoy }}-\gamma\right) H_{w}\right] \tan \varphi / \tan \beta}{\left[\left(\mathbf{q}_{0}+\gamma H\right)+\left(\gamma_{\text {satd }}-\gamma\right) H_{w}\right]} \quad \text { Eq. } 1
$$

Where $c^{\prime}$ is effective cohesion intercept; $\beta$ is the slope angle of natural ground; $\phi$ is the effective angle of friction; $\gamma, \gamma_{\text {buoy }}, \gamma_{\text {satd }}$ are the moist, buoyant and saturated density of soil, respectively; $H$ is vertical thickness (or depth) of sliding surface; $H_{w}$ is the piezometric height above sliding surface; $\mathrm{q}_{0}$ is the uniform vertical surcharge stress on slope and FS is the factor of safety (SCHOR et al., 2007).

Data related to the characteristics of the soil are essential for the application of the algorithm. However, obtaining the data is extremely difficult, since, due to the constant urban expansion, the original soil profile was altered by several landfills created with different materials, which in turn, makes it extremely difficult to have an adequate characterization of the soil, especially due to the area of the urban polygon of $100,37 \mathrm{~km}^{2}$. Thus, considering the aforementioned difficulty, it is necessary to make assumptions about the texture of the soil of the study area. To that end, data related to the average percentages of sand, gravel and silt of the soil in the study area were collected from the Harmonized World Soil Database - HWSD version 1.2 regridded by Wieder et al. (2014). 
According to the aforementioned data, the region's soil has a proportion of $69 \%$ of sand, $8 \%$ clay and $23 \%$ silt, which according to the soil textural triangle created by United States Department of Agriculture - USDA (2017) can be considered as a soil of the sandy loam type. However, the soil of the study area is red yellow acrisol according to the Brazilian Agricultural Research Corporation - EMBRAPA (2001). Acrisols have a higher clay content in their subsoil than in their surface layer according to the Food and Agriculture Organization (2015). Therefore, it was decided to presume for the slope stability algorithm that the soil of the urban area of Garanhuns is of the sandy clay type. Average values for the dry and saturated unit weight of sandy clay soils were obtained through Conduto (2001). While, average values related to the soil cohesion and friction angle were obtained through the soil database of the software Geo5 - Slope Stability (2016).

Considering that according to Schor et al. (2007), the infinite slope model is applied to analyze shallow mass movements, this research considered the depth to the failure surface to be $3 \mathrm{~m}$. Dout et al. (2015) points out that the National Institute of Earth Sciences of Japan classifies mass movements as shallow when the depth to the failure plane is less than $10 \mathrm{~m}$. Therefore, the following soil parameters were used during the modeling process: dry specific weight $=17 \mathrm{kN} / \mathrm{m}^{3}$; saturated specific weight $=19.25$ $\mathrm{kN} / \mathrm{m}^{3}$; submerged specific weight $=9.25 \mathrm{kN} / \mathrm{m}^{3}$; internal friction angle $(\phi)=26^{\circ}$; effective cohesion $\left(c^{\prime}\right)=6$ $\mathrm{kPa}$; depth of sliding surface $=3 \mathrm{~m}$.

The model resulted in a Factor of Safety (FS) and was interpreted in the following way: values equal or less than 1 were considered to be high risk areas, since results inferior to 1 indicate instability according to Tonus (2009); values between 1 and 1,5 were considered as medium risk areas and low risk areas when FS was higher than 1,5 which is required for areas to have a high rate of safety by the Brazilian Standard 11682 written by the Brazilian Association of Technical Standards - ABNT (2006).

It is essential to interpret the safety factor values in order to deduce the slope's susceptibility to mass movements, which according to Mergili et al. (2014) is a spatial probability based on conditions of the local terrain. In order to provide a better comprehension of the system, it is necessary to incorporate all of the objects and elements of the environment and their inter-relationships, whether they result from natural (morphodynamics) or anthropic processes (management/territory).

Therefore, the modeling process performed by the aforementioned algorithm, allows visualization and consequently comprehension of the geomorphological risk while making it possible to compare the geography with socioeconomic factors of the urban occupation in Garanhuns-PE. This fact, gives a new dimension to the discussions made in this research through the results from the on-site visits which aimed to evaluate the situation of the occupied slopes.

\section{RESULTS AND DISCUSSION}

The slope stability model (Fig. 3) provided a clear picture of the geomorphological risk in the urban area of Garanhuns. It was observed that the areas with the highest slope angle are vulnerable to shallow mass movements if the soil becomes saturated. This scenario is increasingly likely due to the constant 
effects of anthropogenic actions in the region, like the construction of houses in very steep slopes.

Results from the model indicate that approximately $2,45 \%\left(1,60 \mathrm{~km}^{2}\right)$ of the urban perimeter has high risk and 9,09\% $\left(5,94 \mathrm{~km}^{2}\right)$ medium risk. These results are worrying, giving that a considerable portion of the slopes are in unstable conditions and are occupied by extensive communities. Furthermore, during the occurrence of mass movements, all of the adjacent area will also be compromised and not only the area considered to be high risk by the model.
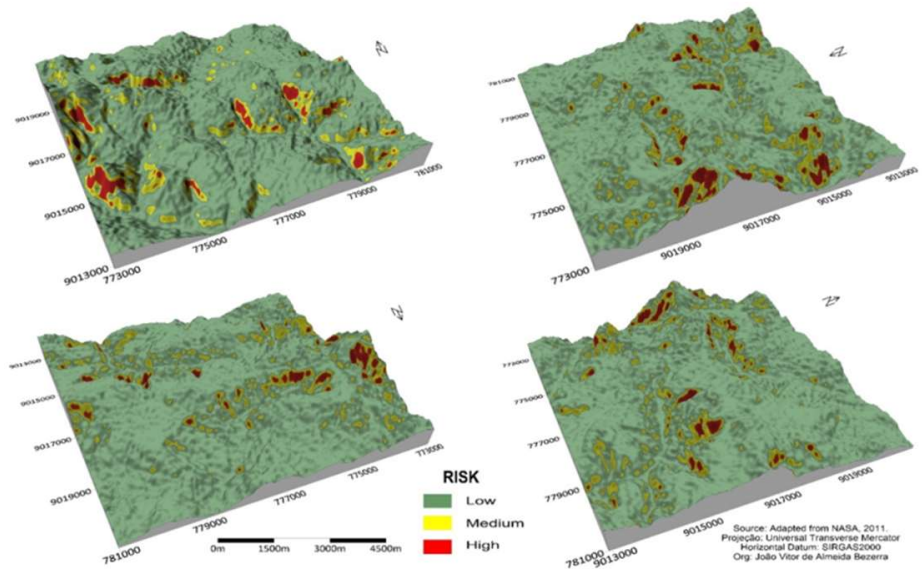

Figure 3: 3D representation of the results from the slope stability model. Source: Adapted from NASA (2011).

Slopes located in urban environments are frequently disturbed by anthropogenic processes like cuts, fills and inadequate disposal of wastewater. A large portion of high-risk areas in Brazil are intensely populated and are under the influence of several types of anthropogenic alterations performed on the landscape (MENDES et al., 2017). The occurrence of mass movements can cause, to the surrounding communities, several negative socioeconomical and environmental impacts. Minimization of these impacts depends on the effective identification of the risk areas, using a process of analysis of the susceptibility to the phenomena (DRAGICEVIC et al., 2015).

Considering that the slope stability model model was applied to the condition of saturated soil, it becomes evident that the urban drainage system is extremely important in order to avoid such scenario, preventing the soils from becoming unstable. In areas with a high slope angle, infiltration of surface runoff increases the soil's pore water pressure and it will decrease the stability of the slope. Controlling the drainage of the surface runoff is recommended as an effective and cheap method for mitigation of mass movements (HAUGEN, 2017).

The urban area of Garanhuns is settled in geographical features, especially hills, that naturally present a susceptibility to the effects of surface runoff. There is also a constant maximization of the urban perimeter in the direction of slopes and the bottom of valleys. Both of these phenomena occur due to the saturation of physical spaces in order to fixate new houses or due to the exacerbated real estate speculation. This scenario occurs due to the lack of an adequate urban planning that takes into consideration the peculiarities of the environment. Several problems arise from the inexistence of urban planning adequate to the environment, like the geomorphological risk, which has intrinsic relations with the hydrological dynamic of the environment, resulting from historical processes of land use. 
Garanhuns and its urban perimeter lack appropriate drainage systems, which aggravates the natural predisposition of its geographical features to erosion (Figs 4A and 4B) and mass movements. Although there are drainage devices in some of the more critical geographical features (Figs $4 C$ and 4D), they aren't implemented in an adequate way, and are often undersized and aren't properly maintained.

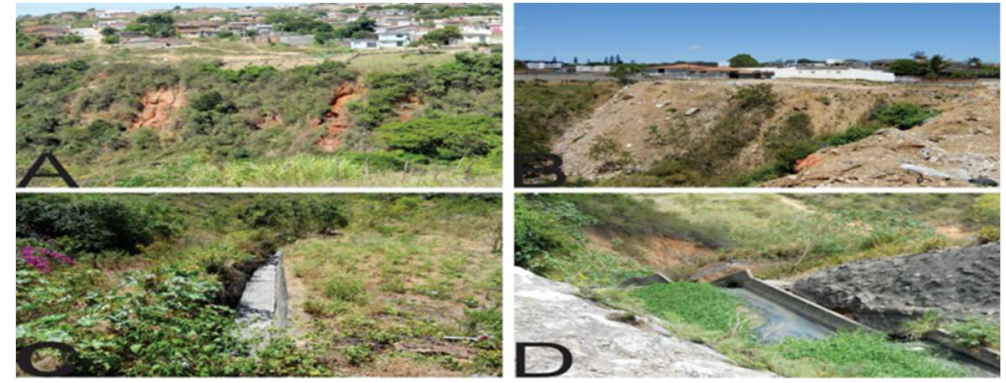

Figure 4: Unstable environments, with latent action of the surface runoff drainage.

The rapid disordered expansion that has been occurring in many cities, especially in developing countries, is responsible for several environmental transformations that often end up changing the environment. The study of urban geomorphology seeks to comprehend the extent to which these changes, caused by men, can be responsible for the acceleration of certain geomorphological processes (GUERRA et al., 2010).

According to Huffner et al. (2017), disordered urban growth is a common reality in the majority of Brazilian municipalities, a fact that generates new challenges to the local governments and is out of the control of several institutions that plan land use. The effects of urbanization on hydrological processes causes damage to the existing urban infrastructure and consequently to society (SURIBABU et al., 2014). The disposal method employed by the drainage system of the study area, optimizes the probability of mass movements on the slopes. These features are being utilized as zones for the expansion of the urban polygon and it's not uncommon to see houses with signs of soil creep and slopes with scars caused by erosion or recent landslides (Figs 5A, B, C and D).
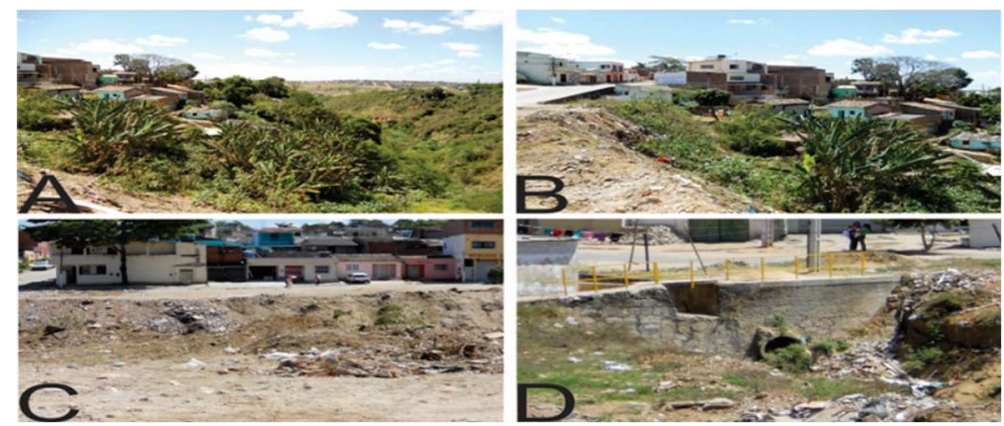

Figure 5: Houses on top of highly unstable slopes.

The aforementioned phenomena turn these geographical features in environments of high geomorphological risk putting the population at a life risk. The problem is aggravated in areas settled by poor communities, due to the fragility of their housing structures and due to the increased length of time that they stay in these constructions during risk situations. Thus, the majority of these citizens do not possess financial conditions that allows them to settle in stable environments, which ends up increasing the 
amount of time that they remain in these areas and reduces their capacity to react during a possible landslide or phenomena related to surface runoff.

There are certain spots in the slopes where surface runoff is used for subsistence farming. Such practices can intensify the erosive processes since the geometry of the slope is altered and there is an increase of concentration of surface runoff. Risk analysis involve several variables like social, environmental and economic. For each of them, there is a temporal question, since, one given variable can have distinct degrees of risk through the passage of time. The risk of mass movements is constant in an occupied slope with a high range of elevation and is aggravated through the passage of time, due to the human waste that is constantly disposed on the slopes (MELO et al., 2016).

Regarding the population's perception of the instability of these environments, the main measures to stabilize the slopes are: usage of residues from civil construction and soils from other slopes. However, such measures are inefficient and may end up creating problems such as: burial of natural springs located in the bottom of valleys, silting of surface water resources, increase of instability of the slopes due to the surcharge that is created and due to the changes that are made to the soil profile.

Urban regions must take a greater responsibility in motivating and implementing solutions that consider the profound connections of their impacts and their existence with the rest of the planet (SEITZINGER et al., 2012). Even with the communities' perception, the population still doesn't give the problem appropriate attention and often end up coming up with clearly inadequate solutions, such as in the Vale da Liberdade, which translates to Freedom Valley, where a trench was excavated in the east side which supposedly would act as a device (Fig. 6A) to drain surface runoff. Even though there is a sporadic occurrence of landslides in the region, the inadequate disposal of residues, the occupation of unstable areas and inadequate farming practices still are common activities in the valley (Figs 6A, B, C and D).
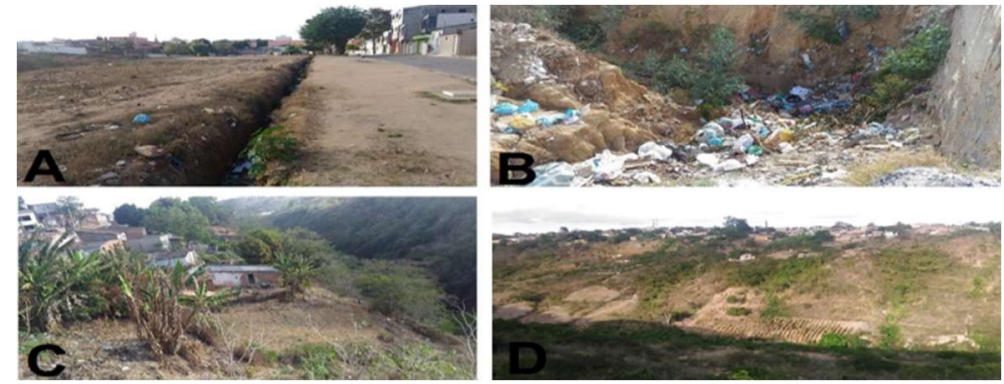

Figure 6: Effects of anthropogenic actions in the Vale da Liberdade in Garanhuns-PE.

Regarding the actions of the public authorities, there is an attempt to mitigate the effects resulted from the displacement of superficial water bodies. The measures are basically the transfer of the problem from one area to another that has a higher capacity to absorb surface runoff and isn't so affected by anthropogenic occupations (Figs 7A, B, C and D). This policy makes it evident that urban planning isn't synonym to mitigation of environmental problems, since the characteristics of the environment aren't always taken into consideration. 

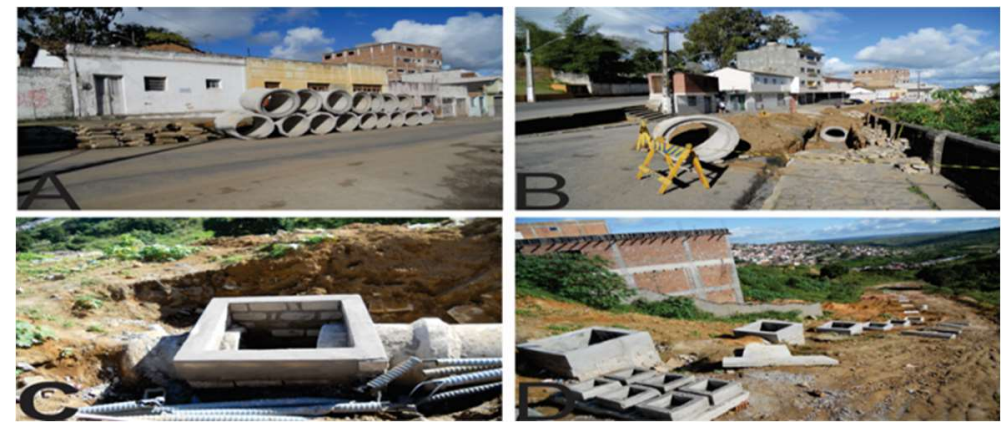

Figure 7: Deviation of the surface water runoff to the bottom of a valley

Soil sealing plays a large role in the amplification of drag force of surface runoff, in such a way that an environment that was previously considered to be stable can become unstable in a matter of minutes, which is a condition associated to the saturation of the soils due to surface runoff caused by rainfall. According to Budhu (2010) water is one of the erosive agents that continuously erodes a slope, altering its geometry and can lead to slope failure creating landslides.

The driest period in Garanhuns happens during mid-September to the end of December, and from January to April the rainfall volume gradually increases, where in the four-month period from May to August, the peak of the rainy season occurs with precipitation exceeding $120 \mathrm{~mm}$ (MELO, 2016). This means that the climate in Garanhuns can create scenarios where the soil can be rapidly saturated. Considering the aforementioned data, it is evident that the geomorphological risk in the urban area of Garanhuns isn't a fixed value, where its intensity is linked to the effects of surface runoff, especially when it's taken into account that the results from the geomorphological risk model pointed out that the slopes are at a high risk if the soils become saturated.

Urban areas have a combination of characteristics that make them responsible for environmental problems in a global scale, as well as leaving them vulnerable to local and global environmental impacts (MESQUITA et al., 2018). Therefore, there is a strong influence of rainfall in the amplification of instable areas, with an emphasis of intense rain events in very steep areas, which besides generating high risk areas, puts the population occupying those spaces at risk.

\section{CONCLUSIONS}

Steep areas with high elevation combined to the constant human occupation create a scenario of geomorphological risk, especially when it is associated with the advance of urban perimeter and the inexistence of drainage systems in areas susceptible to erosion and consequently mass movements.

The model indicated that $2,45 \%$ of the urban area becomes unstable if the soil becomes saturated, which corresponds to a densely populated area and in a possible scenario of mass movements can result in loss of lives as well as a great loss for public coffers. Thus, drainage systems are of paramount importance in order to prevent saturation of the soil which consequently prevents the terrain from becoming unstable.

Based on the on-site work and the subsequent photographical record, it was possible to verify the effects of the anthropogenic actions in the region, which are consequences of an urban expansion without adequate urban planning. This growth of the urban perimeter created several imbalances in the natural 
landscape, especially on the occupied slopes.

It was possible to conclude that analyzing the inter-relationships between urban drainage and geomorphological risk is essential to guarantee an efficient urban planning that will consider the limitations of the landscape and impose measures related to the preservation of the natural ecosystems.

\section{REFERÊNCIAS}

BUDHU, M.. Soil mechanics and foundations. 3 ed. New York: Wiley, 2010.

ABNT. Associação Brasileira De Normas Técnica. NBR 11682/2006. Estabilidade de encostas. Rio de Janeiro: ABNT, 2006

CONDUTO, D. P.. Foundation Design: Principles and Practices. 2 ed. Upper Saddle River: Prentice Hall, 2001.

DOU, J.; PAUDEL, U.; OGUCHI, T.; UCHIYAMA, S.; HAYAKAWA, Y. S.. Shallow and deep-seated landslide differentiation using support vector machines: a case study of the Chuetsu Area, Japan. Terrestrial Atmospheric and Oceanic Sciences, v.26, n.2, p.227-239, 2015. DOI: http://dx.doi.org/10.3319/TAO.2014.12.02.07

DRAGICEVIC, S.; LAI, T.; BALRAM, S.. GIS-based multicriteria evaluation with multiscale analysis to characterize urban landslide susceptibility in data-scarce environments. Habitat International, v.45, n.2, p.114-125, 2015. DOI: http://dx.doi.org/10.1016/j.habitatint.2014.06.031

EMBRAPA. Empresa Brasileira De Pesquisa Agropecuária. Mapa de Solos do Brasil. Rio de Janeiro: IBGE, 2001.

FAO. Food And Agriculture Organization Of The United Nations. World reference base for soil resources 2014 International soil classification system for naming soils and creating legends for soil maps. Roma: FAO, 2015.

GOIS, D. V.; BARBOSA, E.; SOUZA, H. T. R.; REIS, V. S.; SOUZA R. M.. Uso de Espécie Fitoindicadora como Subsídio ao Monitoramento de Mudanças Ambientais em Áreas Urbanas. Revista Brasileira de Geografia Física, v.5, n.4, p. 725-740, 2011. DOI:

http://dx.doi.org/10.26848/rbgf.v5.4.p725-740

GUERRA, A. J. T.; MARÇAL, M. S.. Geomorfologia Ambiental. 3 ed. Rio de Janeiro: Bertand Brasil, 2010.

HAUGEN, B. D.. A design method for landslide surface water drainage control. Environmental \& Engineering Geoscience. Washington, v.23, n.4, p.275-289, 2017. DOI: http://dx.doi.org/10.2113/gseegeosci.23.4.275

HUFFNER, J. G. P.; OLIVEIRA, A. R. F.. Crescimento urbano desordenado no município de Ponta de Pedras na llha do Marajó: um estudo de caso do bairro do Carnapijó.

InterEspaço: Revista de Geografia e Interdisciplinaridade, v. 3, n.8, p.159-181, 2017. DOI:

http://dx.doi.org/10.18764/2446-6549.v3n8p159-181

IBGE. Instituto Brasileiro de Geografia e Estatística.

Geociências: Malhas Digitais. 2013.

INMET. Instituto Nacional de Meteorologia. Banco de Dados Meteorológicos para Ensino e Pesquisa, 2013.
MELO, F. P.. Modelo de uso e ocupação da paisagem no município de Garanhuns - PE. Reget, v.10, n.10, p.21982207, 2013. DOI: https://doi.org/10.5902/223611707857

MELO, F. P.. Risco Ambiental e Ordenamento do Território em Garanhuns-PE. Tese (Doutorado em Geografia) Universidade Federal de Sergipe, São Cristóvão, 2016.

MELO, F. P.; SOUZA, R. M.. Produção de Áreas de Risco Geomorfológico no Sítio Urbano de Garanhuns-PE. In: SOUZA, R. M.; SANTOS, S. S. C.; SANTOS, E. A.; KOHLER, R. Cenários Urbanos: riscos e vulnerabilidade na gestão territorial. Aracaju: Criação, 2016, p.67-104.

MENDES, R. M.; ANDRADE, M. R. M.; GRAMINHA, C. A.; PRIETO, C. C.; ÁVILA, F. F.; CAMARINHA, P. I. M.. Stability analysis on urban slopes: case study of an anthropogenicinduced landslide in São José dos Campos, Brazil.

Geotechnical and Geological Engineering, v.36, n.1, p.599610, 2017. DOI: https://doi.org/10.1007/s10706-017-0303-z

MERGILI, M.; MARCHESINI, I.; ALVIOLI, M.; METZ, M.; SCHNEIDER-MUNTAU, B.; ROSSI, M.; GUZZETTI, F.. strategy for gis-based 3-D slope stability modelling over large areas. Geoscientific Model Development, v.7, n.6, 2014. DOI: https://doi.org/10.5194/gmd-7-2969-2014

MESQUITA, P. S.; BURSZTYN, M.. Alimentação e mudanças climáticas: percepções e o potencial de mudanças comportamentais em prol da mitigação. Desenvolvimento e Meio Ambiente, v.49, p.1-16, 2018. DOI: http://dx.doi.org/10.5380/dma.v49i0.54835

MONTEIRO, S.; FREIRE, G. S. S.; Cunha, L.. Percepção dos riscos de cheias e inundações na cidade da praia (Cabo Verde). Revista Eletrônica do PRODEMA, v.11, n.1, p.117129, 2016. DOI: https://doi.org/10.22411/rede.v11i1.364

NASA. National Aeronautics and Space Administration. ASTER GDEM. 2016.

OLIVEIRA; A. A.; BORGES, J. T.. Análise da vulnerabilidade populacional aos riscos tecnológicos ambientais na área urbana da cidade de Manaus-AM. Desenvolvimento e Meio Ambiente, v.49, p.283-304, 2018. DOI: http://dx.doi.org/10.5380/dma.v49i0.59260

SEITZINGER, S. P.. Planetary stewardship in an urbanizing world: beyond city limits. Ambio. Stockholm, v.41, p.787794. DOI: https://doi.org/10.1007/s13280-012-0353-7

SCHOR, H. J.; GRAY, D. H.. Landforming: an environmental approach to hillside development, mine reclamation and watershed restoration. Hoboken: Wiley, 2007.

SILVA, F. M. A.; BANDEIRA, A. P. N.; RIBEIRO, S. C..

Mapeamento de áreas de risco geomorfológicos no distrito 
do Caldas-Barbalha-CE: caso do núcleo urbano do sítio Riacho do Meio. Revista Geoaraguaia, v.8, n.2, p.1-18, 2018

SURIBABU, C. R.; BHASKAR, J.. Evaluation of urban growth effects on surface runoff using SCS-CN method and GreenAmpt infiltration model. Earth Science Informatics, v.8, n.3, p.609-626, 2014. DOI: https://doi.org/10.1007/s12145-0140193-z

TONUS, B. P. A.. Estabilidade de taludes: avaliação dos métodos de equilíbrio limite aplicados a uma encosta coluvionar e residual da serra do mar paranaense. Thesis (Masters in Geotechnical Engineering) - Universidade Federal do Paraná, Curitiba, 2009.

USDA. United States Department Of Agriculture. Soil Survey Manual, 2019.

WIEDER, W. R.; BOEHNERT, J.; BONAN, G. B.; LANGSETH, M.. Regridded Harmonized World Soil Database, 2014.

A CBPC - Companhia Brasileira de Produção Científica (CNPJ: 11.221.422/0001-03) detém os direitos materiais desta publicação. Os direitos referem-se à publicação do trabalho em qualquer parte do mundo, incluindo os direitos às renovações, expansões e disseminações da contribuição, bem como outros direitos subsidiários. Todos os trabalhos publicados eletronicamente poderão posteriormente ser publicados em coletâneas impressas sob coordenação da Sustenere Publishing, da Companhia Brasileira de Produção Científica e seus parceiros autorizados. Os (as) autores (as) preservam os direitos autorais, mas não têm permissão para a publicação da contribuição em outro meio, impresso ou digital, em português ou em tradução. 